\title{
Improving the Methodological Support for Recording Expenditures and Outcomes of R\&D
}

\author{
Galina Aleksandrovna Mashentseva ${ }^{1} \&$ Zinaida Aleksandrovna Kostina ${ }^{1}$ \\ ${ }^{1}$ Kamyshin Technological Institute (a branch of Volgograd State Technical University), Kamyshin, Russian \\ Federation \\ Correspondence: Galina Aleksandrovna Mashentseva, ap. 25, house No. 3, drive Egorova, Kamyshin, Volgograd \\ region, 403874, Russian Federation
}

$\begin{array}{lc}\text { Received: February 28, } 2015 & \text { Accepted: March 20, } 2015 \quad \text { Online Published: April 24, } 2015 \\ \text { doi:10.5539/res.v7n6p12 } & \text { URL: http://dx.doi.org/10.5539/res.v7n6p12 }\end{array}$

\begin{abstract}
At present, the evaluation of the results of innovation is important when choosing promising investment projects for all levels of management-from economic entities interested in the implementation of innovative strategies to federal authorities responsible for science, technology and innovation policies in the country. At the same time, great importance in our country is given to an innovative way of development of enterprises that perform research and development activities (R\&D), as evidenced by the increase of the share of innovative research nearly 2.5 times over the last five years. Successful intensification of $R \& D$ process is due to the creation of innovation centers: "Skolkovo", "Technopark-Sarov", Technopark of Novosibirsk Akademgorodok, "Technopark-Strogino" and others that are designed to maximize territorial cohesion of science, industry and commerce. The existing regulatory framework for R\&D accounting does not allow to defining a clear distinction between "research" and "development" and therefore regulates only the end result of these activities. This leads to a distortion in the formation of expenditures for R\&D and unreliable monetary terms relating to their outcomes. In addition, in the current practice, the problems of application of international accounting standards still remain open, which adversely affects the attraction of foreign investors. As a solution to the existing problems, it is necessary to use the fundamental principle of national accounting) time definiteness of the facts of expenditures and outcomes of R\&D - when making professional judgment. The unresolved problems in the recognition of expenditures and outcomes of $R \& D$ in accounting and reporting result in an increased interest in conducting special studies to find effective methodological support for innovation management that meets the different needs of users of financial statements.
\end{abstract}

Keywords: innovation, research, accounting, reporting

\section{Introduction}

Innovative development of the Russian economy is currently being implemented through the introduction of the results of scientific research into the activities of the economic entity. The result of the research, development and engineering activities is normally not defined, which indicates high risk of performing research and development activities (R\&D). Under these conditions, not only introduction of the results of research and development is important, but also the accuracy of the information formed about the expenditures of economic entities for search, development, implementation and commercialization of new products and technologies.

Despite the importance of the processes associated with both the implementation of research activities and experimental development of new technologies and new products, there is problem of the proper definition of R\&D, the solution of which depends, first of all, on the recognition of expenditures for research and development, taking into account their specificity.

However, a study of legal documents showed that there is currently no clear definition of R\&D, and, respectively, no formation of adequate financial information about them in the accounting and annual financial statements.

The study of norms of these laws has shown the existence of different approaches to the concept of activities that lead to methodological difficulties in the formation of the results of these processes in accounting. 
Table 1. Approaches to the definition of types of scientific and experimental activities

\begin{tabular}{|c|c|c|}
\hline Concept & Federal Law dated 23.08.96 No.127-FZ & Federal Law dated 28.09.10 No.244-FZ \\
\hline & $\begin{array}{l}\text { Preparation and application of new } \\
\text { knowledge in terms of: }\end{array}$ & \\
\hline $\begin{array}{l}\text { Research activities / } \\
\text { Scientific (scientific }\end{array}$ & $\begin{array}{l}\text { 1) Fundamental scientific research, } \\
\text { which is understood as the following } \\
\text { activities: experimental or theoretical, } \\
\text { associated with the acquisition of } \\
\text { knowledge with an element of novelty; }\end{array}$ & $\begin{array}{l}\text { Conducting research, development and } \\
\text { commercialization of the results in the } \\
\text { following areas: }\end{array}$ \\
\hline research) activities & $\begin{array}{l}\text { 2) Applied scientific research, which is } \\
\text { understood as research related to the } \\
\text { application of knowledge with an } \\
\text { element of novelty to solve practical } \\
\text { problems }\end{array}$ & $\begin{array}{l}\text { 1) Energy efficiency and conservation, } \\
\text { including development of innovative } \\
\text { energy technologies; } \\
\text { 2) Nuclear technology; } \\
\text { 3) Space technology, including in the }\end{array}$ \\
\hline $\begin{array}{l}\text { Scientific and technical } \\
\text { activities }\end{array}$ & $\begin{array}{l}\text { Preparation and application of new } \\
\text { knowledge to solve the following } \\
\text { problems: technological, engineering, } \\
\text { economic, social, humanitarian; as well } \\
\text { as to create a unified system of } \\
\text { functioning of science, technology and } \\
\text { production }\end{array}$ & $\begin{array}{l}\text { field of telecommunications and } \\
\text { navigation systems; } \\
\text { 4) Medical technologies in the } \\
\text { development of equipment, drugs; } \\
\text { 5) Strategic computer technologies and } \\
\text { software }\end{array}$ \\
\hline $\begin{array}{l}\text { Experimental } \\
\text { development }\end{array}$ & $\begin{array}{l}\text { Conducting research based on the use } \\
\text { of new knowledge and practical } \\
\text { experience }\end{array}$ & \\
\hline
\end{tabular}

The approaches to the definition of types of scientific and experimental activities listed in the table are not interconnected with the concepts of accounting items, such as: research, development and engineering activities.

The result of carrying out scientific research is the formation of scientific and technical information in the form of a documented report with the relevant calculations or confirmed experiments, with its subsequent commercialization, i.e. receiving future economic benefits. Therefore, carrying out research work is not confined to the creation of material samples of products.

It is important to note that the main features of the contract related to the implementation of research and development activities are the following:

1) Novelty of the results of scientific research;

2) Possibility of creating new intellectual property assets, regulated by Article 1225 of the Civil Code of the Russian Federation, in particular, the new inventions, utility models, industrial designs.

Difference between research and development works is in the creative pursuits.

\section{Materials and Methods}

The unsolved problem of methodological support of the implementation of the principle of time definiteness of facts of economic life is the order of recording of the expenditures by the R\&D stages and results in accounting.

Exploring the current method of synthetic accounting of the expenditures for $R \& D$, the influence of the following factors on it was revealed:

1) Firstly, of the method of activities: In-house or through subcontractors. In this case, the in-house implementation can involve separate divisions or a special department of the economic entity, which will also lead to different expenditure records;

2) Secondly, of the conditions for recognition of expenditures for R\&D as an object of accounting "expenditures";

3) Thirdly, of the conditions for recognition of a positive or negative result of R\&D.

The study of the methodology of in-house accounting of expenditures for R\&D in accounting practice and 
economic literature revealed the existing problems with the development of recommendations to improve the accounting of these expenditures.

For example, a survey of accounting practices of the investigated companies revealed that many of them use account 23 "Auxiliary production" to record the in-house expenditures for R\&D, which according to the comments of the Instructions for the use of plan accounts of financial and economic activities of organizations, approved by order of the Ministry of Finance of Russia dated 31.10.2000 No.94n, is intended to summarize the information about the expenditures of auxiliary production in relation to primary production. At that, the debit of account 23 "Auxiliary production" subaccount "Auxiliary research unit" summarizes expenditures associated with the implementation of R\&D and indirect expenditures for management and maintenance.

However, this approach to cost accounting of activities on the account 23 contradicts to the paragraph 5 of the Russian Accounting Standards (RAS) 17/02, which points to the need to record information about the innovative activity at the account 08 "Investments in non-current assets".

This rule contained in the RAS 17/02 in respect of the capitalization of the costs of carrying out scientific research is due to the fact that such costs are seen as a strategic asset, rather than the current cost of doing business (Rudenko, 2004). This approach is consistent with the principle of matching revenues and expenditures, where the costs of research and development (R\&D) may be capitalized or deferred, and when the revenue can be received, these costs are recognized as incurred.

The methodological approach of recording current expenditures is quite common in international practice (Rudenko, 2004), as it is due to the fact that the period of income is unknown, it is difficult to establish a link between revenues and expenditures and therefore it is impossible to reliably estimate the income derived from the use of results of these activities. In addition to this argument, the economic literature contains a point of view that the costs should not be put off if there is no guarantee that they can be covered by future revenues and be able to bring profits in subsequent periods.

Technique of formation of R\&D indicators in the accounting and financial reporting is currently based on the norms of RAS 17/02 that governs the reflection of expenditures and results of R\&D in the financial statements. This technique is schematically represented in scientific papers (Figure 1).

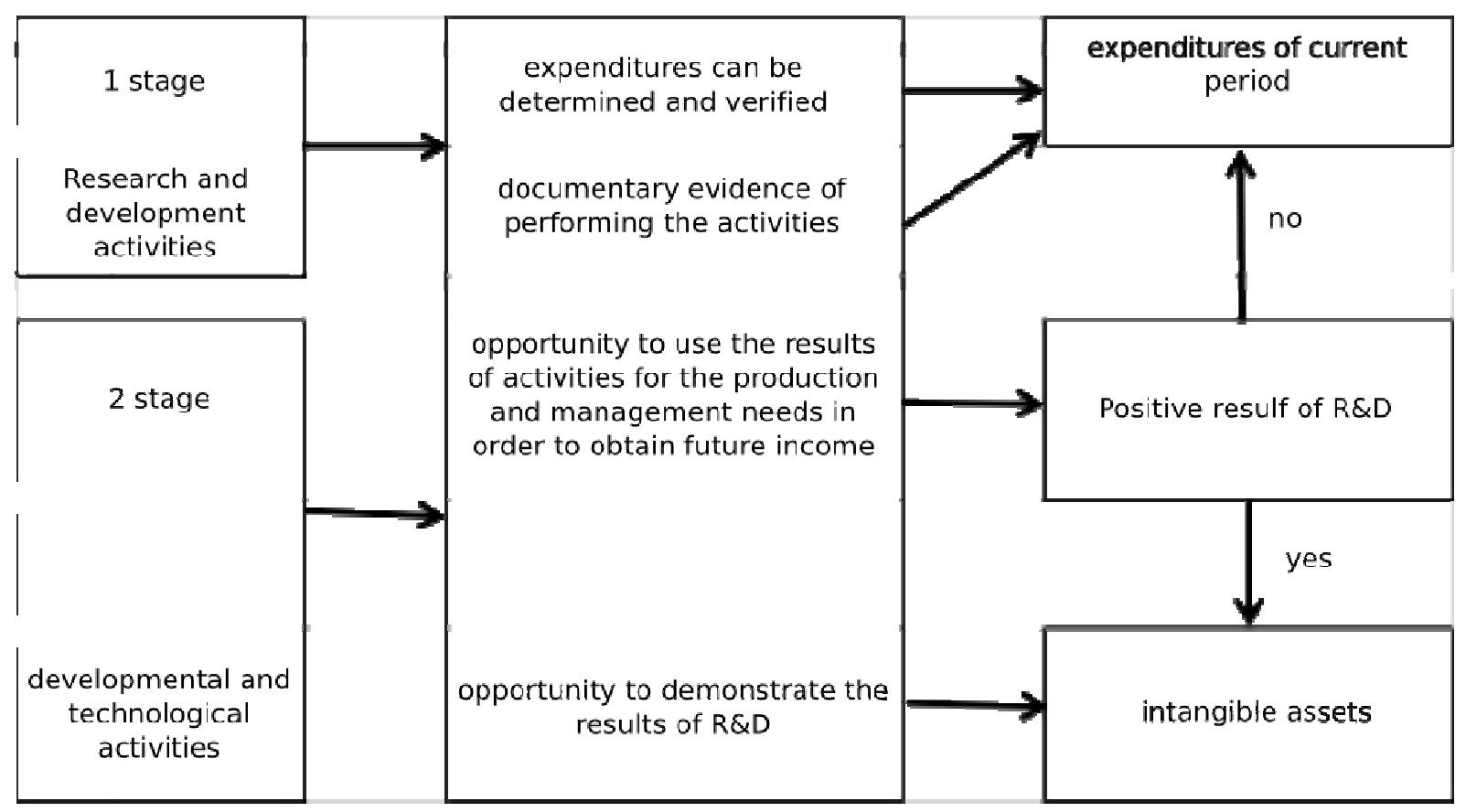

Figure 1. Recording the expenditures for R\&D in accordance with Russian standards

However, the order of formation of information on innovative activity of economic entities cannot be based only on the rules of the accounting standard (RAS 17/02), because it requires changes in connection with the backlog of ongoing changes in the accounting reform. Therefore, due to lack of information on innovation to form a 
complete picture of the financial position of the audited entity, financial results of its operations and the changes in its financial position, the Ministry of Finance of the Russian Federation recommends to include additional indicators and explanations to the statements.

\section{Results}

Improving the methodological support for recording expenditures and outcomes of R\&D is based on a proper understanding of the economic substance of the facts of the studied objects of accounting innovation. Existing legal documents do not give an unambiguous interpretation of research, development and engineering activities, which leads to a distortion of financial information in the accounting and reporting.

The study of the rules of domestic law on innovation, civil and tax laws, RAS 17/02 "Accounting of expenditures for research, development and engineering activities" and International Accounting Standards (IAS) 38 "Intangible Assets" (IA) has allowed to make conclusion of methodological difficulties in formation of data on the expenditures and results of R\&D on the stages of research and development. So, the issues of distinguishing the concepts of research and development are covered in RAS 17/02, which has references to the provisions of the Federal law regulating the issues of science and state science and technology policy. However, this law does not reveal the economic interpretation of the facts of implementation of developmental and technological activities. Based on the rules of RAS 1/2008, which in the absence of definite decisions on the issue of organization of the accounting allow to use international accounting standards, we recommend to recognize developmental and technological activities as objects of observation of accounting at the stage of development, while the research activity is to be recognized as objects of observation of the accounting at the stage of research.

When performing the following activities: research and development, an important part is the recognition of expenditures for the execution of these activities and their results in accounting. The accuracy of the recognition of expenditures and results of $R \& D$ depends on the correct application of accounting principles, where the most important is the principle of the time definiteness, which allows to determine the moment of recognition not only of the expenditures for $R \& D$, but also assets in the form of $R \& D$ results, obtained by the capitalization of costs.

As for the rules of recognition of expenditures for $R \& D$ in accounting and the record of their results, they are defined in the RAS 17/02:

1) Amount of expenditures is determined and confirmed;

2) Documents confirming the implementation of $R \& D$ are available (in particular, the act of acceptance of the performed R\&D);

3) Results of $R \& D$ in the production and (or) management purposes will determine the flow of future income (economic benefits);

\section{4) Demonstration of $R \& D$ results.}

These rules do not take into account the specifics of unfinished works and therefore may not be applicable to the recognition of the expenditures for unfinished work. Furthermore, the standard does not introduce the concept of "unfinished R\&D", which significantly affects the organization of cost accounting. Based on the principle of time definiteness of facts of economic activity, we believe that the unfinished R\&D should be recognized as the costs of the contract (order) that are recognized in the period in which they are incurred, i.e. the actual costs incurred are recommended to include costs relating to the started but not finished works. This accounting item can be both on the research and development stages. However, in recognition of the costs of research projects, one should base on the rules of IAS 38, where the costs are recorded as current expenses as incurred, as there is no certainty of the future income at the research stage. Therefore, the costs at the research stage are not subject to capitalization, and therefore do not create asset value.

It should be noted that in terms of IAS 38, expenditures for R\&D do not represent an independent accounting item and are seen as a way to create an intangible asset. Thus, in accordance with international standards, the stage of creation of intangible asset includes works at the stages of research and development. However, according to RAS 17/02, expenditures for R\&D are an independent accounting item that does not intersect with the subject of the records in the form of an intangible asset. This difference in the regulated subject is due to the differences in the criteria for recognition of the intangible asset in the domestic and international accounting standards.

The above conditions for the recognition of R\&D objects in accounting are systematized and presented in Table 2. 
Table 2. Recommendations for the implementation of the principle of time definiteness of the expenditures depending on the result of R\&D

Conditions for Recommendations for use of conditions of Comparison of conditions for recognition recognition of the RAS 17/02 for recognition of the expenditures of the expenditures for R\&D according to

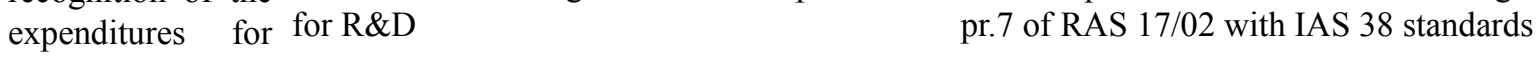

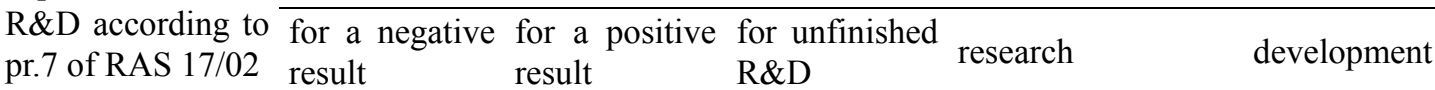

Amount of Condition is satisfied in the presence of Possibilities to reliably determine the expenditures is primary accounting documents confirming the amount of expenditures

determined and cost measurement of expenditures

confirmed

Documents Condition is satisfied in the Condition is Condition is not Condition does not

confirming the presence of documents not satisfied satisfied exist

implementation of confirming the completion of because of the

$\mathrm{R} \& \mathrm{D}$ are available activities or their stages inability to

confirm the

completion of

activities or

their stages

Use of results of Condition is satisfied provided Condition $R \& D$ in the that the result of $R \& D$ is applicable in future economic intangible assets is

is Lack of confidence Creation of production and likely and in the presence of from the time benefits and the technically possible, (or) management previous results of previous when the flow recognition of funds are available purposes in order research, which suggest that of future expenditure for for completion of to determine the they are promising for benefits is research in the the work on the flow of future subsequent commercialization probable period they occur development stage. income (economic benefits) without There are intention capitalization in the and ability to apply formation of the the created IA in the value of intangible enterprise, or there assets is an intention to implement it. Asset will create probable income (economic benefits) because there is a market and the need for the IA use is justified

Use of R\&D Condition is not Condition Condition is Condition is not Condition is results can be satisfied because is satisfied not satisfied satisfied because of satisfied demonstrated of the inability to because of the the inability to demonstrate an inability to demonstrate an asset that will lead demonstrate asset that will lead to the creation of an asset that to the creation of economic benefits will lead to economic benefits the creation of economic benefits

\section{Discussion}

Studies have shown that in the practice of economic entities, the internal reserves are formed, suggesting the existence of obligations within the organization. These reserves in domestic practice are represented by reserves for future expenses that are necessary for the uniform formation of prime cost, which will affect the amount of 
the financial result of the reporting period. At the calculation of these reserves, it is necessary to define its norm, which determines the probable or inevitable expenses during the reporting period. In this case, there is no information on the amount of expenditures and when they occur at the time of the reserve creation.

However, in order to reduce the economic burden, it is necessary to have economically justified calculations in the form of estimates for the creation of a reserve.

In the absence of precise information on the amount of costs to be included in the reserves, the values are sampled that are essential for determining the amount of the reserve. This approach is based on the prudence concept and directed to preservation of capital. According to Terekhova V. A. (Terekhova, 2011), using the prudence concept, it is necessary to set the range between the upper and middle amount of the reserve. In practice, the upper limit is set in the amount exceeding $20 \%$ of the average amount of the reserve. As for the amount of the average value of the reserve, it should lead to a reduction of assets with a probability greater than $95 \%$.

In addition to the estimated liabilities for innovation, creation of valuation reserves is also important.

Studies have shown that this category includes reserves recorded at the accounts that regulate/clarify evaluation of assets subject to cost reduction: accounts receivable (account 63 "Provisions for doubtful debts"), financial investments (account 59 "Provisions for impairment of financial investments"), materials, goods, finished goods, work in process (account 14 "Provisions for impairment of tangible assets") (Generalova, Pyatov, \& Smirnova).

These reserves do not represent any one of the following accounting items: assets, liabilities, equity. In accounting theory, they are presented as "contractives", amplifying the valuation of assets.

It should be noted that IAS requires clarification of valuation of not only the financial assets (including receivables) and inventories, but also the intangible assets, fixed assets and investment property in accordance with IAS 36 "Impairment of Assets".

According to Generalova and Pyatov M. L. (Generalova, Pyatov, \& Smirnova), these contractives must be called "valuation reserves", because:

1) These reserves have the estimating, subjective nature (as well as "valuation liabilities");

2) Application of the term "reserves" to this category reflects one of the meanings of reserves- the source, through which the losses are subsequently covered.

Studies have shown that there are recommendations for the formation of valuation reserves in the process of scientific research in the economic literature. This is due to the fact that the development of innovation is related to the long period of their creation, resulting in the risk of uncertainty in obtaining revenues in the case of commercialization of innovative projects (Sidorenko, 2011).

Thus, it is proposed to take a free number in the first section of the Chart of Accounts-account 06 entitled "Provision for innovation" (Perekrestova, 2012) to record the provision for innovation. This account will be characterized as passive in relation to the balance, therefore, the operations to create a provision will be credited to the account 06, operations to use or write-off reserves will be debited (Sidorenko, 2011).

As for the accounting provisions for tax purposes, since 01.01.2012, on the last day of the reporting (tax) period, the other costs are recognized as expenses on the formation of reserves for future R\&D expenditures (pr. 1, art. 264 of the Tax Code of the Russian Federation, supplemented with pr. 39.3).

Such a provision is created separately for each program of $R \& D$, as recorded in the accounting policies. The period for which a reserve is created must comply with the plan of work, not exceeding two years, and is also reflected in the accounting policies.

Within the prescribed period, the upcoming expenses are reserved, where all actual costs for R\&D during the reporting (tax) period are written off against the amount of the created reserve. If the reserve is not sufficient, or, on the contrary, it is unnecessarily credited, then adjustments are made, during which the target costs are "brought" to the actual or vice versa: the actual costs are brought to the target.

\section{Conclusion}

These recommendations for improving the surveillance objects in the performance of $R \& D$ at the stages of research and development have led to changes in the balance sheet and the statistical form No.4-Innovation.

As for the balance sheet, we recommend to enter the expenditures for $\mathrm{R} \& \mathrm{D}$, valuation reserve to change in the amount for the expenditures for $R \& D$, valuation reserve to change the amount of positive results of $R \& D$, valuation liabilities for innovation in the sections I "Non-current assets", II "Current assets" and V "Current 
liabilities" as separate items and regulatory items.

Considering the procedure for filling statistical forms, the studies have shown that the information in them was formed without dividing the costs by research and development stages, and therefore did not significantly characterize the result of innovative activity of the economic entity. In addition, there is currently no procedure of interconnecting the items of accounting (financial) reporting with data in statistical forms, allowing to significantly transforming the performance of financial reporting into the information for the system of national accounts. Given these recommendations, it is necessary to collect information for the forms No.4-Innovation and No.2-Science from the sources presented in Table 3.

Table 3. Recommended sources to form the major economic indicators of form No.4-Innovation

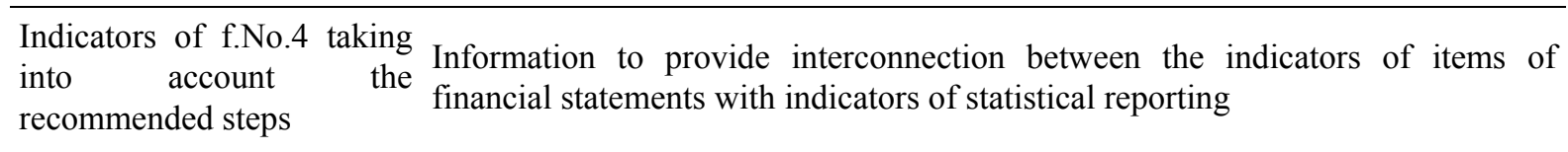

Costs of technological Balance Sheet items: "Inventories"; "Valuation liabilities", incl.: "Provisions innovation, including: established for innovation".

1) Research stage Items of Profit and Loss Statement: "Prime cost", "Other expenses" (in the amount of valuation reserves).

2) Development stage Balance Sheet items: "Expenditures for R\&D"; "Valuation reserve to change the amount of the expenditures for R\&D"; "Valuation liabilities", incl.: "Provisions established for innovation".

Items of Profit and Loss Statement: "Prime cost", "Other expenses" (in the amount of valuation reserves).

Notes to the Balance Sheet and Profit and Loss Statement for R\&D

Costs of marketing Balance Sheet items: "Inventories"; "Valuation liabilities", incl.: "Provisions innovations established for innovation".

Costs of organizational Item of Profit and Loss Statement: "Prime cost"

innovations Notes to the Balance Sheet and Profit and Loss Statement for R\&D

Developed recommendations for the introduction of new indicators in the balance sheet are the basis of the formation of macroeconomic generalizations of innovation results by special statistical forms. In addition to the balance data, the information is required on the costs of innovation, which is formed in the budgets for innovation. In this regard, it is suggested to use a form of the roadmap of the innovative project developed by the author, which is shown in the work.

Thus, the developed theoretical propositions and recommendations for improving the methodological support for accounting expenditures and outcomes of R\&D of Russian economic entities will allow to reliably generating information on innovative activities in the context of research and development stages.

\section{References}

Balashov, A. I., Rogova, E. M., \& Tkachenko, E. A. (2010). Innovative Activity of Russian Enterprises: Issues of Measurement and Growth Conditions. Saint Petersburg: Publishing of the St. Petersburg State Polytechnic University.

Frascati Manual. (2005). Proposed Standard Practice for Surveys on Research and Experimental Development. Paris: OECD Publications.

Gazizova, A. R. (2011). Accounting of In-House Innovation in Vertically Integrated Structures. Naberezhnye Chelny: Samara State University of Economics.

Generalova, N. V., Pyatov, M. L., \& Smirnova, I. A. (n.d.). Application of IAS: Linguistic and Terminological Problems. Retrieved from http://www.buh.ru/document-1608

Ilyshev, A. M., Ilysheva, N. N., \& Voropanova, I. N. (2005). Accounting and Analysis of Innovation and 
Investment Activities of the Organization: a Tutorial. Moscow: KNORUS.

Kochergin, (2011). Innovation: Tax Exemptions and Preferences. Financial Newspaper, 7.

Makarova, L. G., Mansurova, I. V., \& Stefan, M. A. (2012). Objects of R\&D: Accounting and Recording in the Financial Statements in Accordance with Russian and International Standards. International Accounting, 11.

Mashentseva, G. A. (2012). Issues of Reliability of Indicators of Innovation in the Financial Statements. Scientific Review, Series 1. Economics and Law, 6, 5.

Mashentseva, G. A. (2013). Methodology of Synthetic Accounting of the Expenditures for R\&D in Science and Technology Business. Kazan Science, 1.

Myasnikov, O. A. (2011). Creating Favorable Tax Conditions for Innovation. Accounting and Taxation in Budget Organizations, 9 .

Oslo Manual. (2005). The Measurement of Scientific and Technological Activities. Proposed Guidelines for Collecting and Interpreting Technological Innovation Dat. Paris: ECD Publications.

Perekrestova, L. V. (2012). Disclosure of Information on the Innovation Activities of the Organization in Accordance with International Financial Reporting Standards. Terra ECONOMICUS, 10(1), Part 2.

Platonov, V. V. (2003). Resource Support for Innovation. Saint Petersburg: SPSUEF.

Predeus, N. V. (2010). Methodological Aspects of Accounting Principles by Subjects of Investment and Construction Activities. Management of Economic Systems, 4.

Rudenko, N. V. (2004). Business Practices of Accounting Expenditures for R\&D. Library of "Rossiyskaya Gazeta", 22.

Sidorenko, A. Y. (2011). Innovative Activity in the Accounting System of the Enterprises. Proceedings of the Session. Volgograd: Publ. VolSU.

Sizonova, O. (2011). Cost Accounting for R\&D within the Operational Contracts. Autonomous Organizations: Accounting and Taxation, 7.

Sokolov, Ya. V., Patrov, V. V., \& Bykov, V. A. (2007). Financial and distribution accounts: Recording income and expenses by accounting periods. Accounting, 6, 46-52.

Terekhova, V. A. (2011). About the Formation of Reserves in the Organization in the Conditions of Economic Instability. Everything for the Bookkeeper, 2(254).

Yasikova, A. (2010). Comparative Characteristics of Accounting Intangible Assets in IAS and RAS. Financial Newspaper, 20.

\section{Copyrights}

Copyright for this article is retained by the author(s), with first publication rights granted to the journal.

This is an open-access article distributed under the terms and conditions of the Creative Commons Attribution license (http://creativecommons.org/licenses/by/3.0/). 